\title{
FISHING, CONSUMPTION, AND PROCESSING OF FISH AND SHELLFISH IN THE EASTERN ADRIATIC THROUGH THE LONG MIDDLE AGES
}

\author{
Sabine Florence Fabijanec \\ Hrvatska Akademija Znanosti i Umjetnosti \\ CroATIA
}

Date of receipt: $30^{\text {th }}$ of October, 2018

Date of acceptance: $11^{\text {th }}$ of June, 2019

\section{Abstract}

The article first presents a review of historical evidence on the presence and use of different species of fish in the eastern Adriatic (statutes and other normative sources, notarial documents, travelogues, literary sources, etc.). Secondly, it provides a survey of the fishing grounds found along the Croatian shoreline. The third part briefly summarizes some of the basic rules and the evolution of fishing techniques. The last part deals with the market and some aspects of domestic life in terms of the processing and consumption of various underwater species (tuna fish, shellfish and corals).

\section{KeYWORDS}

Fishing, Fishery, Fish $\&$ shellfish consumption, Croatian eastern Adriatic, Middle Ages, Sixteenth century.

\section{Capitalia verba}

Piscatio, Piscatus, Consumptio piscum et conchyliorum, Mare Hadriaticum orientale croatense, Medium Aevum, Saeculum sedecimum. 


\section{Introduction ${ }^{1}$}

The Adriatic Sea extends from northeast to southeast for about $870 \mathrm{~km}$. Its depth is separated by a virtual line that goes up to the promontory of Gargano on the Italian side, and joins the islands of Mljet (Meleda) and Lastovo (Lagosta) through Palagruža (Pelagosa), on the Croatian side. The northwest basin of this line is rather shallow and uniform. Its maximum depth is $270 \mathrm{~m}$ at the surroundings of the island of Jabuka (Pomo). At the southeastern basin the deepest part reaches 1,223 $\mathrm{m}$ and all of that area is quite deep. Since the Adriatic is a semi-closed sea it is physically and ecologically isolated, creating a specific biocenose. ${ }^{2}$ What do the written sources tell us about the diversity of marine fauna during the medieval period?

Several sources enable the gathering of information about fish and the communal life that takes place around fishing activities. ${ }^{3}$ Records describe what kind of fish is caught with what kind of techniques and how common some species may be in a given area. There are maps which show the location of the fishing grounds. Visual supports, images from medieval and early modern times, provide original or technical information. The historiography completes the existing data and provides topics for further research. All these elements of the same puzzle help to create a vivid description of the which, where, how and at what price fish is consumed in the Croatian maritime coastline of the eastern Adriatic.

\section{Written sources about species and frequency of fish and fishing techniques}

The examination of existing records makes it possible to list a large number of marine species present in the eastern Adriatic between the $8^{\text {th }}$ and the $16^{\text {th }}$ century (Table 1). Altogether 58 species can be identified. Among them some species appear recurrently in the sources.

The most frequently documented fish are sardines (clupea pilchardus), common dentex (dentex dentex), red mullet (mullus barbatus), mackerel (scomber scomber), picarel (spicara smaris) and bluefin tuna (thynnus thynnus).

\footnotetext{
1. This work has been supported in part by the Croatian Science Foundation under the project "Sources, Manuals and Studies for Croatian History from the Middle Ages to the End of the Long Nineteenth Century" (IP-2014-09-6547). Used abbreviations: BnF, Bibliothèque nationale de France; DADZ, Državni Arhiv u Zadru; DAST, Državni Arhiv u Split.

2. Bello, Gianbattista. "The cephalopod fauna of the Adriatic". Acta Adriatica, 31/1-2 (1990): 275-291.

3. Archaeology provides evidences for earlier periods. See Florido, Erica; Auriemma, Rita; Faivre, Sanja; Radić Rossi, Irena; Antonioli, Fabrizio; Furlani, Stefano; Spada, Giorgio. "Istrian and Dalmatian fishtanks as sea-level markers", Quaternary International, 232 (2011): 105-113.
} 


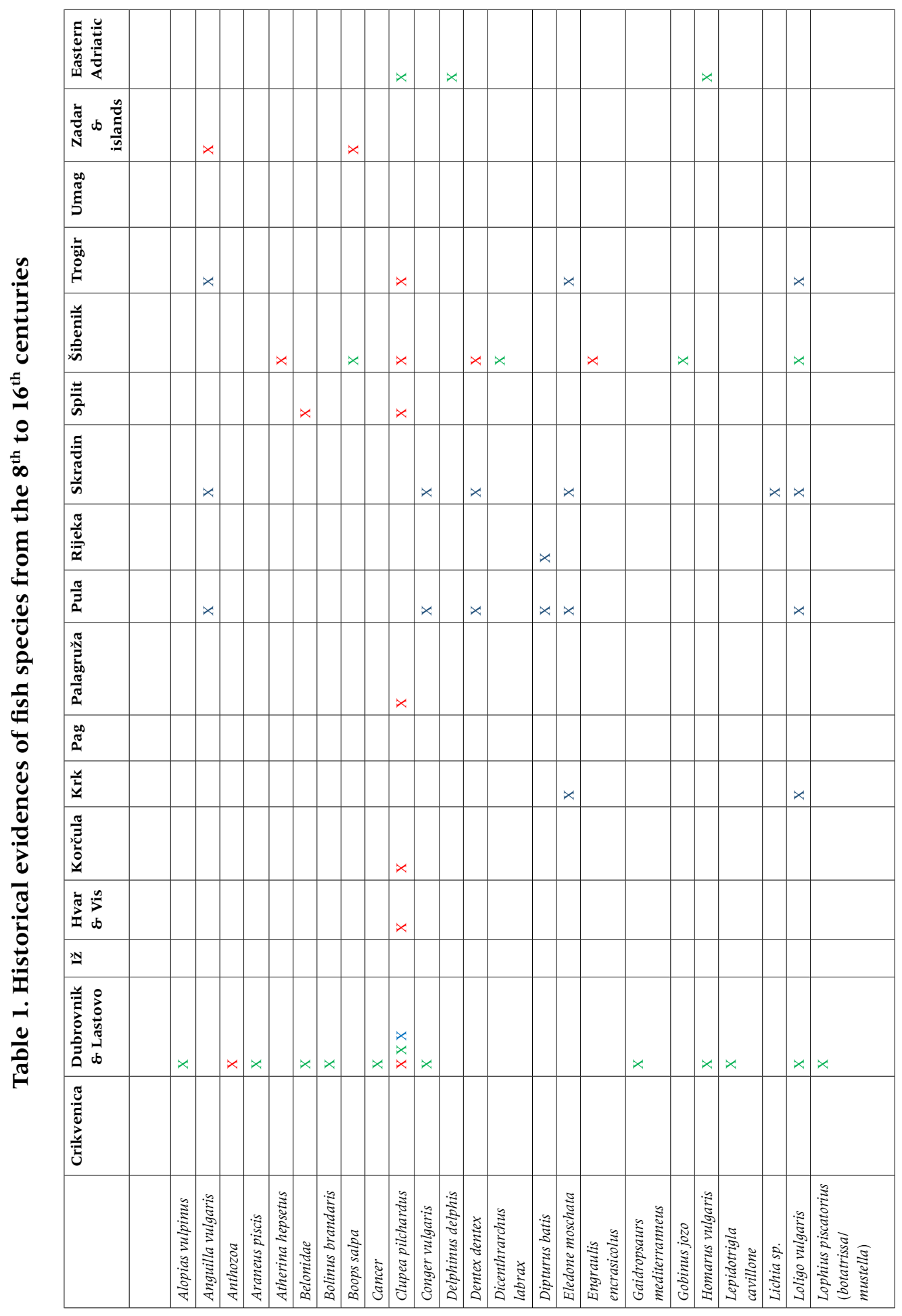




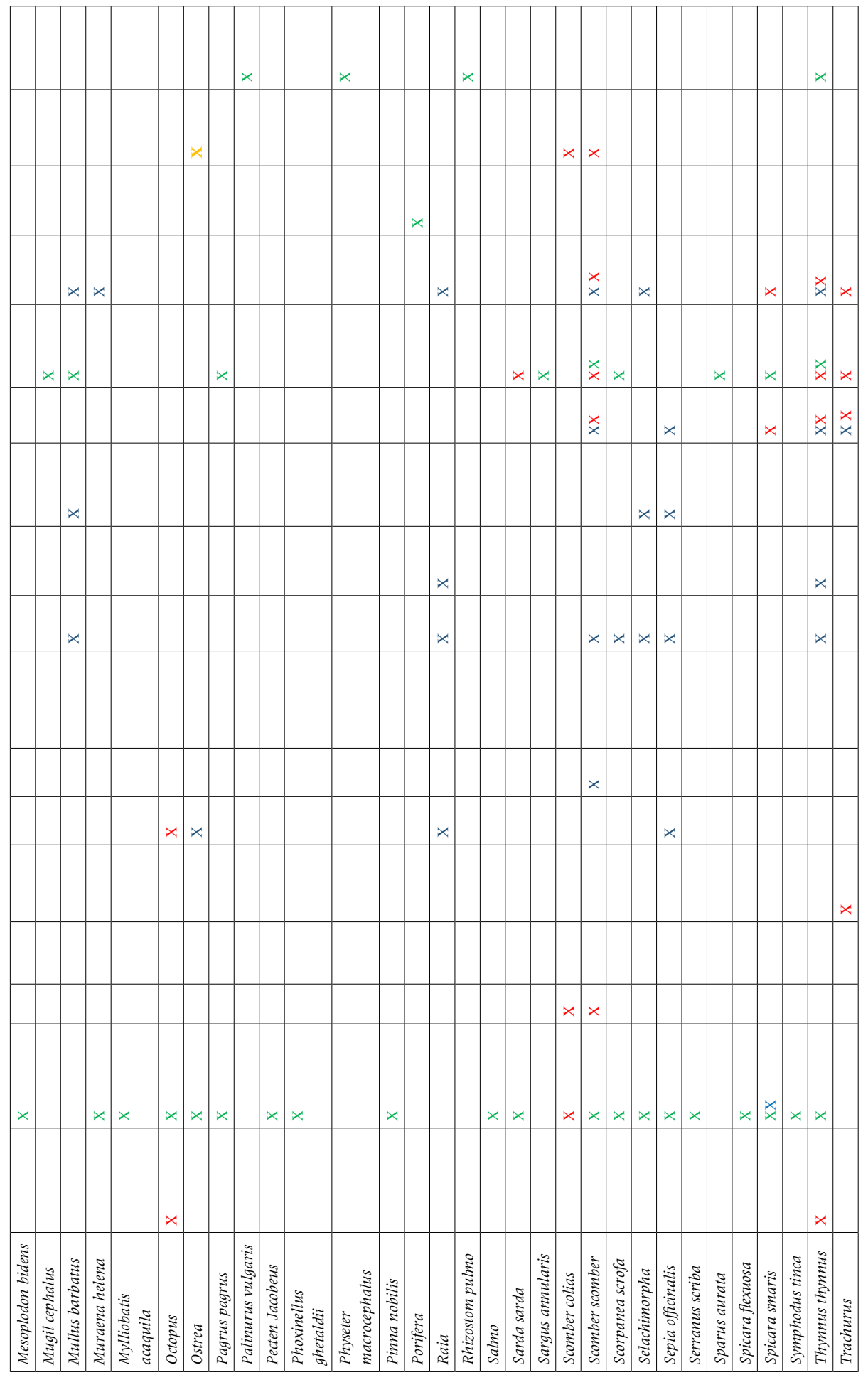




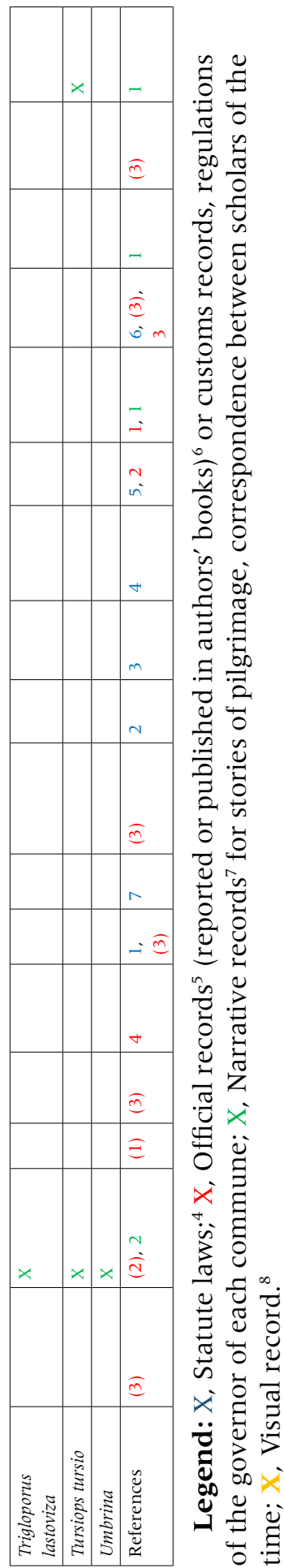

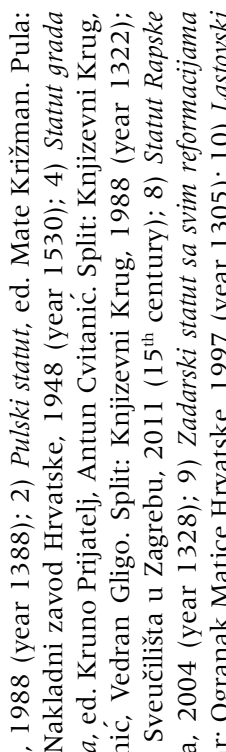

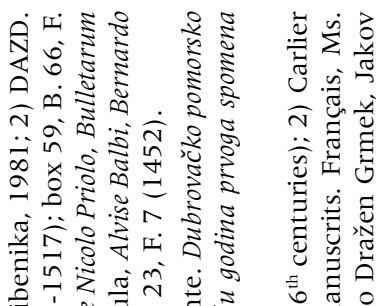

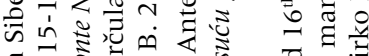

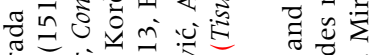

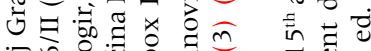

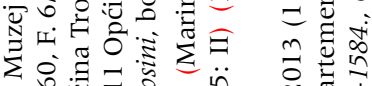

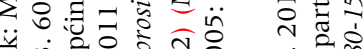

节

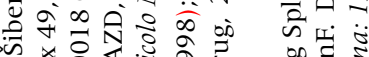

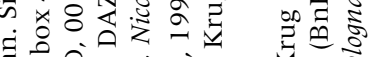

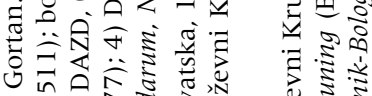

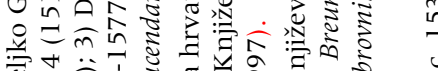

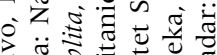

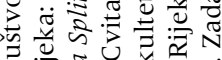

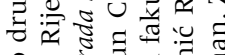

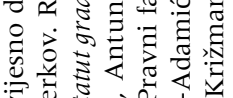

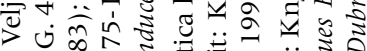

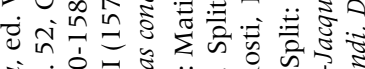

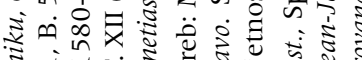

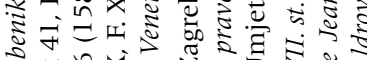

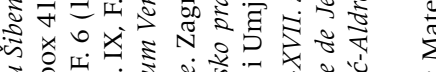

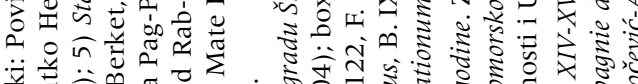

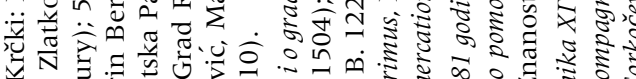

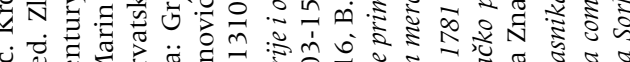

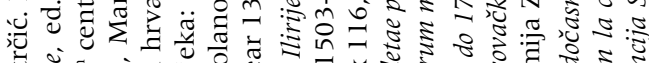

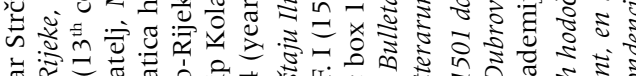

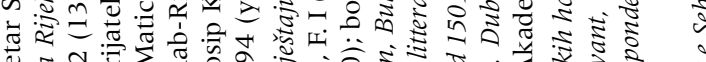
๘

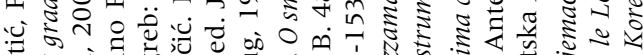

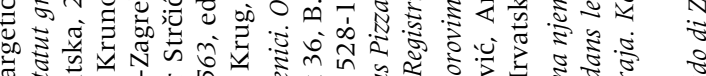

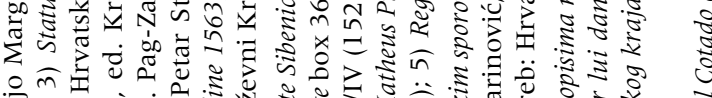
药

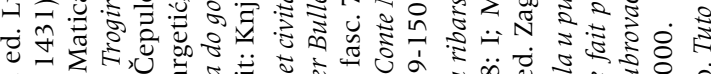

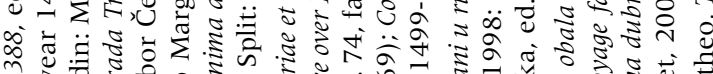

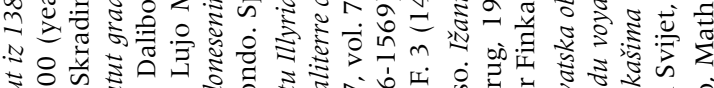

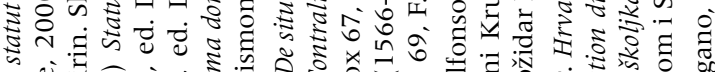

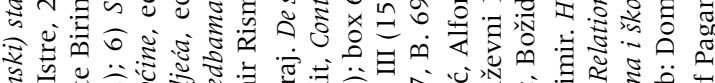

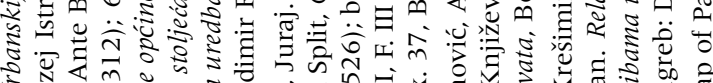

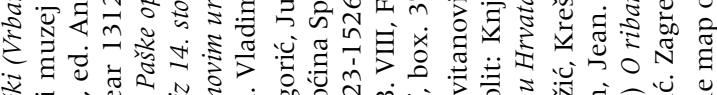

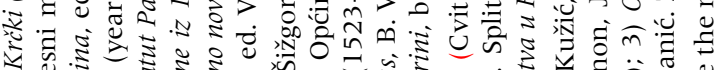

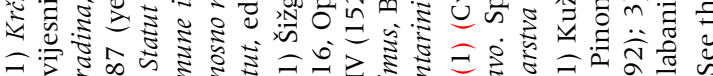

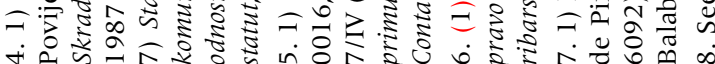


Among cephalopods there are musky octopus (eldone moschata), squid (loligo vulgaris), common octopus (octopus vulgaris) and cuttlefish (sepia officinalis). Rays (raia) are the only chondrichthyes mentioned and oyster (ostrea) are the only bivalves mentioned. These data from the historical evidence are more or less consistent with current observations.

Indeed in the Adriatic the most common fish species are the above-mentioned sardine, mackerel, bluefin tuna and in general other pelagic fish (also called oily fish or dark flesh fish), ${ }^{9}$ while in the shallows the most common fish is picarel. ${ }^{10}$ However, while a census from the 1990s identified more than 40 species of cephalopod, in the sources only four types are mentioned. ${ }^{11}$ Dentex is present along the entire Adriatic coast. It is mostly located on rocky bottoms with overgrown Neptune grass, though it can be found on shelled, coral and sandy bottoms. The common habitats are 5 to 30 meters deep. ${ }^{12}$ Red mullet inhabits sandy and muddy bottoms, mostly in depths down to 200 meters. $^{13}$

Dolphins are not directly linked with fishing activities, but they appear in the eastern Adriatic in the travel stories of pilgrims. Among sailors, dolphins enjoy a reputation for heralding bad weather. The testimonies of German pilgrims between 1461 and 1579 contain instances of this: five times a storm broke out after dolphins were observed or they appeared during a full storm. These cetaceans are even purchased on some occasions as a kind of hunting trophy. For example, after lunch on a sunny day in 1461 in the waters of Dubrovnik (Ragusa), one of the pilgrims was watching some dolphins playing around the galley. He takes a spear and throws it at the dolphins. The speared dolphin is so strong that he escapes with the broken tip in his body. ${ }^{14}$ According to current data the only cetacean species that resides in

9. White fish is a fisheries term for several species of demersal fish with fins. They live on or near the seafloor, and can be contrasted with the oily or pelagic fish which live in the water column away from the seafloor. Whitefish contain oils only in their liver, rather than in their gut, and can therefore be gutted as soon as they are caught, on board the ship. Dark fleshed fish live in the pelagic zone of ocean. They are also called oily fish since they have oil in their tissues and in the belly cavity around the gut. Their fillets contain up to $30 \%$ oil, although this figure varies both within and between species. Examples include small forage fish, such as sardines, herring and anchovies, and other larger pelagic fish, such as salmon, trout, tuna, swordfish and mackerel. They are suitable for preservation (salting or brine) and for a further trade of salted/brine fish. 10. Fabijanec, Sabine Florence. "Fishing and the fish trade on the Dalmatian coast in the late Middle Ages", The Inland Seas Towards an Ecohistory of the Mediterranean and the Black Sea, Tonnes Bekker-Nielsen, Ruthy Gertwagen, ed. Stuttgart: Franz Steiner Verlag, 2016: 369.

11. Bello, Gianbattista. "The cephalopod...." 284-285.

12. Luša, Lucia. Važnost bijele ribe u prehrani čovjeka. Šibenik: Veleučilište u Šibeniku-Odjel Menadžment, 2016: 24-25.

13. Tserpes, Georges; Fiorentino, Fabio; Levi, Dino; Cau, Angelo; Murenu, Matteo; Zamboni, Ada; Papaconstantinou, Costas. "Distribution of Mullus barbatus and M. surmuletus (Osteichthyes: Perciformes) in the Mediterranean continental shelf: implications for management". Scientia Marina, 66/2 (2002): 39-54.

14. Kužić, Krešimir. Hrvatska obala u putopisima njemačkih hodočasnika XIV-XVII. st., Split: Književni Krug Split, 2013: 218, 299. 
the Croatian part of the Adriatic Sea and that could have been observed by pilgrims is the bottlenose dolphin (Tursiops truncatus). ${ }^{15}$

Schools of fish migrate seasonally from one area to another. The following summary of the fishing grounds (called pošta in the Croatian region, from the Italian posta: luogo asegnato o scelto per la pesca $)^{16}$ make it possible to specify the species of fish that swim in particular in the waters of the various maritime communal territories from Istria to southern Dalmatia. Each year, these posta are assigned to various groups of fishermen by draw.

\section{An overview of fishing zones along the Croatian eastern Adriatic}

Studies have already been carried out on the fishing areas and the fishponds established in the waters of various communes along the coast and in island areas, since basically each commune has its own fishery. In addition to the communal posta, throughout the 11th century private fisheries appear, especially for the benefit of the Church. Below, an overview of fishing zones from the north-west to the southeast is presented, bearing in mind that this geographical outline doesn't necessarily fit the chronology of the fishing of some species — which will be highlighted where appropriate.

\subsection{Istria}

The first data on privileged fishing originate from 543 when the diocese of Poreč (Parenzo) acquires from the bishop the right to fish in the bay of Lim (Leme) (See illustration 1). Then in 983, the fishing season is documented in the bay of Tar (Turris) (It should be noted that since these are politico-diplomatic sources, no mention is made of their concrete application in everyday life.) ${ }^{17}$ In Dalmatia, thanks to a dispute among aristocrats in Zadar, we learn about the existence of fisheries since 986 - which corresponds to the same period, the end of the 10th century. ${ }^{18}$

\footnotetext{
15. Vuković, Snježana; Lucić, Hrvoje; Đuras Gomerčić, Martina; Galov, Ana; Gomerčić, Tomislav; Ćurković, Snježana; Škrtić, Darinka; Domitran, Goran; Gomerčić, Hrvoje. “Anatomical and histological characteristics of the pituitary gland in the bottlenose dolphin (Tursiops truncatus) from the Adriatic Sea". Veterinarski arhiv, $81 / 1$ (2011): 144.

16. "posta: assigned or chosen place for the fishing". Miotto, Luigi. Vocabolario del dialetto veneto-dalmata. Trieste: Lint, 1991: 160.

17. Codice diplomatico Istriano, ed. Pietro Kandler. Trieste: Tipografia del Lloyd Austriaco, 1862: I, 49-50 (doc. No. 20), 179-180 (doc. No. 82).

18. Codex diplomaticus Regni Croatiae, Dalmatiae et Slavoniae, ed. Jakov Stipišić, Marko Šamšalović. Zagreb: Academia Scientiarum et Artium Slavorum Meridionalium Auxilio Regiminis Croatie, Dalmatie et Slavoniae, 1967: I, 49-51 (doc. No. 34).
} 


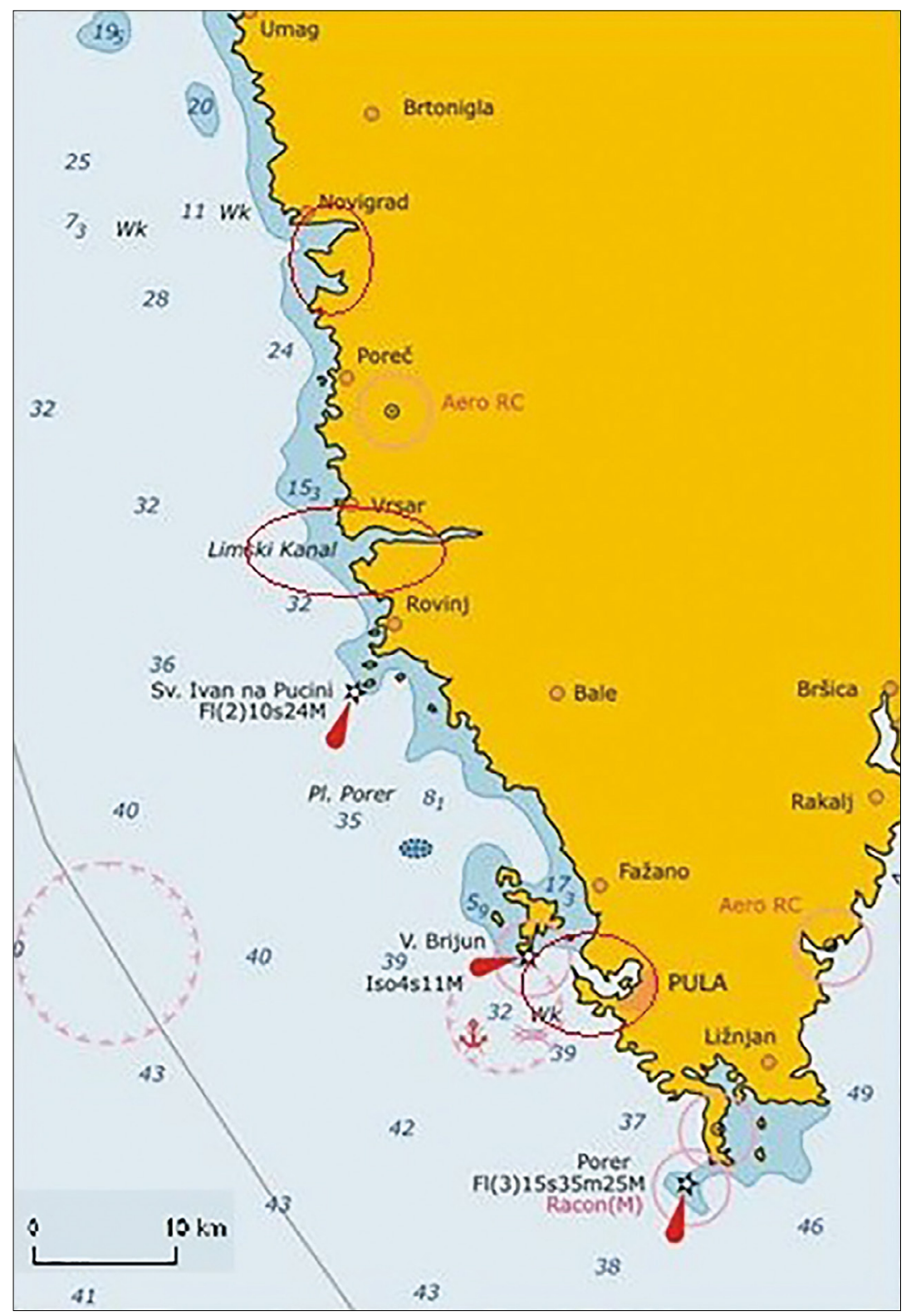

Illustration 1. Fishing ZONES ON THE WESTERn Istrian COAST. MAP PROVIDED By the AUTHOR . 
The earliest mention of tuna fishing is in Pula (Pola). According to the statute from 1382, the fishing season lasted from August to mid-October. ${ }^{19}$ In the area of Rovinj (Rovigno), the fishing of tuna was regulated from the $15^{\text {th }}$ century. Chapter 61 mentions Poste delle pescatori concerning fisheries of tuna and Atlantic bonito that are drawn. The statutes mention two kind of nets: the special gillnet for catching tuna (tonere) and common nets (rette). In Poreč there is only one mention from 1540 of a tuna fishery, and it was under the ownership of the bishop. ${ }^{20}$

\subsection{Kvarner}

A tunera, a fishing zone for tuna, is documented on the island of Rab (Arbo; See Illustration 2) from the very end of the $15^{\text {th }}$ century. Tuna are preserved in brine. Fishermen usually lease the right to fish in the water belonging to the chapel of Saint-Georges' island in the neighbourhood. They need to give up one tenth of the fish caught to the priest and to pay him a fee in addition. Around the waters of Rijeka (Fiume) there was a defined fishing ground for tuna from 1438 at the bay of Preluka. Gillnets were installed in this bay and observation ladders were erected on the side The basin was available for every communal fisherman, and in 1458 the fishing period was extended to Sundays and holidays, ${ }^{21}$ which shows the willingness of the local authorities to improve production levels.

On the island of Krk (Veglia) a tuna fishery is mentioned at a later date, from 1527, to the north in Omišalj (Castel Muschio). This peschiera di thunni is leased by the Chamber of Krk for a period of five years for 100 ducats. $^{22}$

\subsection{Northern Dalmatia}

Blagoslovi Bože slavni pored s nami svi ribari. Blagoslovi Bože slavni i njih brodi s mrižami. Da bi dosti ulovili i ubozima udilili.2.

19. Franceschi, Camillo de. "Gride del comune di Pula degli anni 1381-1382". Archeografo triestino, serie 3, 4 (1928): 338-341; Statuto del comune di Pola, ed. Bernardo Benussi. Parenzo: Tipografia Gaetano Coana, 1911. 20. Basioli, Josip. Tunolov na Jadranu. Zagreb: Jadranski Institut Jugoslovenske Akademije Znanosti i Umjetnosti, 1962: 27-28.

21. Basioli, Josip. Tunolov na Jadranu...: 31, 44-45.

22. Basioli, Josip. Tunolov na Jadranu...: 38-41.

23. "Glorious God bless among us all fishermen. Glorious God bless their ships with their nets. So they catch enough to share with beggars." Translated from Croatian by the author. Excerpt of a prayer from the $16^{\text {th }}$ c. from the island of Olib. Starešina, Petar. Pomorstvo Silbe. Zadar: Jugoslavenska Akademija Znanosti i Umjetnosti, 1971: 14. 


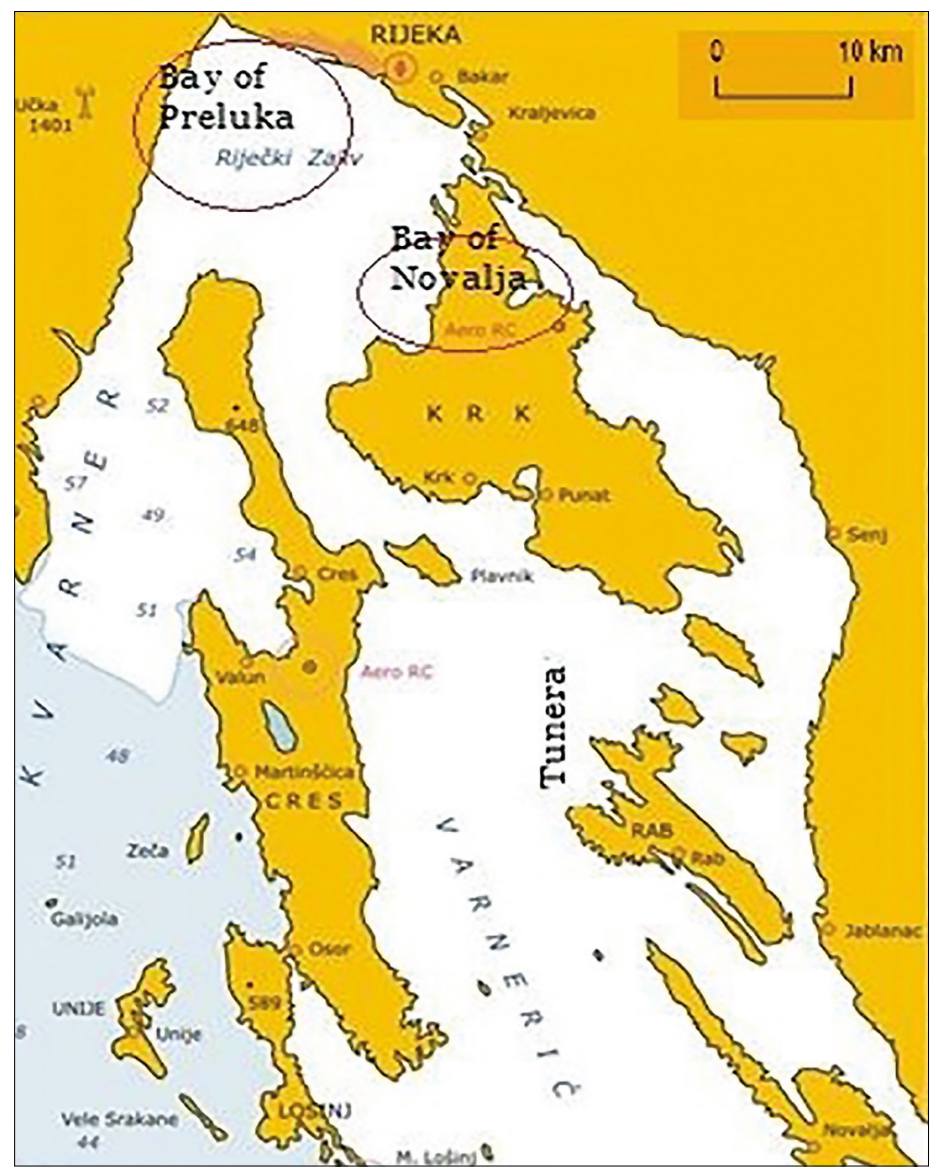

Illustration 2. Waters of the Kvarner area. Map provided by the AUTHOR.

The fertile bays of Sakarun and Telašćica on Dugi otok (Isola Lunga) are the most representative productive basins (piscationis) of the archipelago of Zadar (Zara; see Illustration 3). The right to fish is first legally mentioned in 986 when, due to internal disputes between members of the Zaratin urban nobility, the priors sold a quarter of the fishing zones of Molat Island and the bay of Telascica on Dugi otok to the Benedictine monastery of St. Krševan. This right is extended by the monastery in 1078: from then on all fishermen are required to deliver one quarter of their catch to the Benedictines to obtain the right to fish in these fertile zones. ${ }^{24}$ Evidence of systematic exploitation is registered from the second half of the $15^{\text {th }}$ century, 


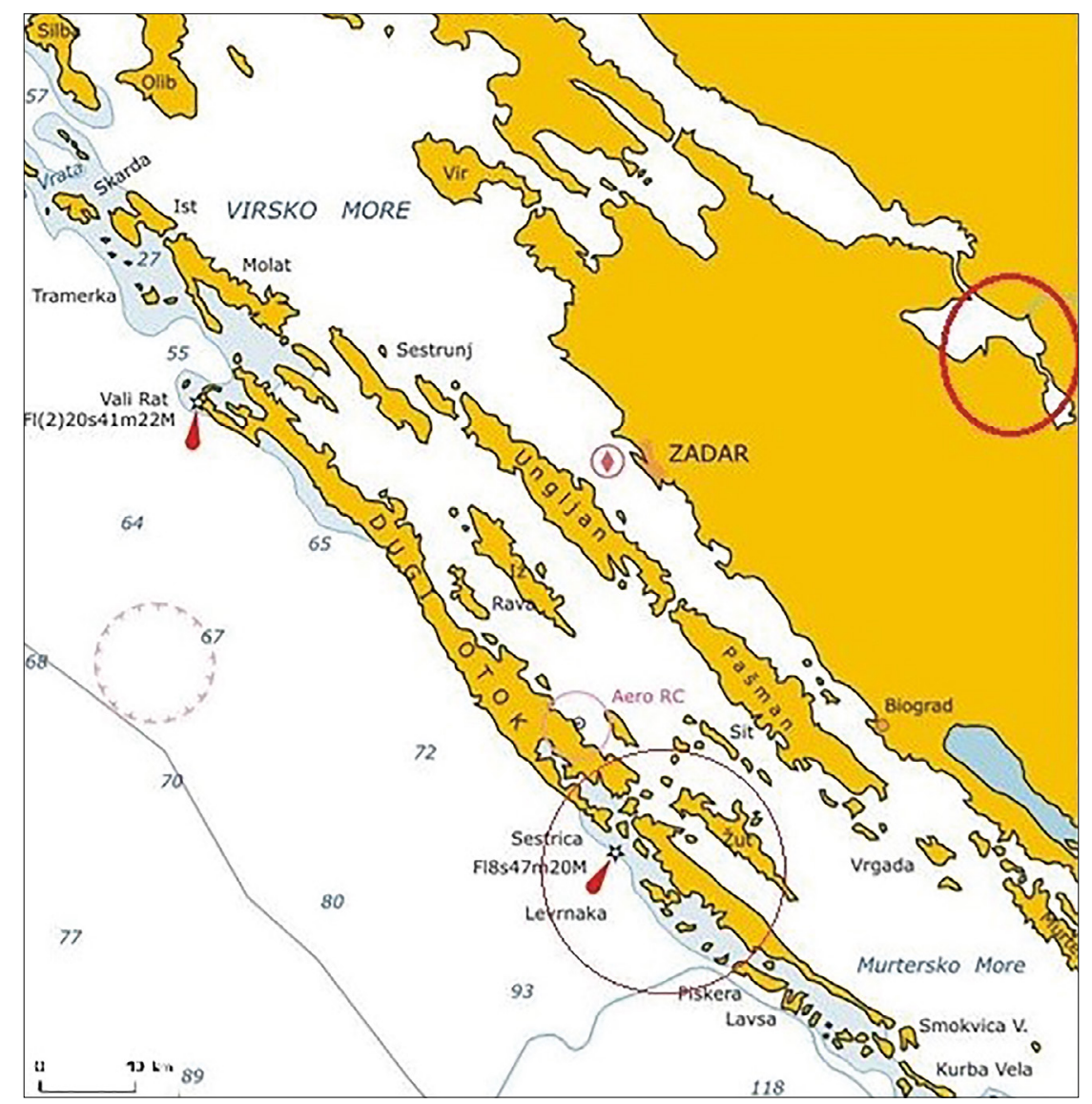

Illustration 3. Archipelago of Zadar. Map provided by the author.

again because of disputes over fishing rights. ${ }^{25}$ Fishermen spend up to 20 days at sea during the summer. Thus, taking into consideration the combined productions of Novigrad (Citta Nova), Rab and Pag (Pago) it was possible to catch up to 15 tonnes of fish per year in the $15^{\text {th }}$ and $16^{\text {th }}$ centuries. ${ }^{26}$

Encircled by other islands of the Zadar archipelago, the island of Iž (Eso) has easy access to fishing areas. When a dispute broke out in 1501, the population of Iž claimed that its right to fish in the areas of Sakarun and Molašćica dated back to 1431. Fishermen of the other islands leagued together against the inhabitants of Iž. It is because of this dispute that we are better acquainted with the details of the

25. Fabijanec, Sabine Florence. "Fishing and the fish trade...": 370.

26. Starešina, Petar. Pomorstvo Silbe...: 11 ; Piasevoli, Andrea. "Fragmenti iz ekonomskog života Zadra od XIII do XVIII st.". Zbornik Zadra, 38 (1964): 40-41. 
fishing process inside the Zadar archipelago. The fishing season lasts four to five months, from the end of March to the middle of June, while some considered it possible to fish until July, or even until the $29^{\text {th }}$ of September. ${ }^{27}$ The inhabitants of Iž are permitted to fish for two nights, while the other islanders can fish for eight nights in a row. Once their quality has been checked, the 212 driftnets (calculating around three fishing boats with 14 to 16 fishermen for one net) are awarded by drawing lots with a die, which denotes the choice of the bay where each group of fishermen is allowed to fish. The waters of the Zaratin archipelago are especially popular for mackerel fishing. These are pelagic fish (called pesce erranti or pesce migratorie, sciami $d e^{\prime} i$ pesci $i^{28}$ in the sources), of the family of scombri and clupeidae, whose arrival on the shores of the eastern Adriatic takes place in March. ${ }^{29}$

These facts are widely known by historians, but another intriguing fact has been largely overlooked: the existence of an oyster farming area in Novigrad bay as shown on a $16^{\text {th }}$ century map (see illustration 3 ). Apart from this visual document there are no references to it elsewhere.

\subsection{Coral harvesting}

Haec quoque florescit speciosis unda corallis,

Qui dites Indos, antipodasque petunt..$^{30}$

From the second half of the $15^{\text {th }}$ century in the basin of Šibenik (Sibenico) the new technique of driftnet fishing for catching dark-fleshed fish spread widely, with addition of lighting for dark days fishing. In addition to this type of fishing, the inhabitants of the island of Zlarin (Slarino; see Illustration 4) had become specialised in the catching of red coral (coralium rubrum). Coral reefs are between 30 and in 200 meters deep. In the $14^{\text {th }}$ century these coral fishermen were accused of frightening sardines and their activity raised strong protests. ${ }^{31}$ Coral harvesting took place from

27. Cvitanović, Alfonso. Ižani u ribarskim sporovima od 1501 do 1781 godine. Zagreb: Matica hrvatska, 1998: 84-85.

28. "stray fish", "migratory fish", "swarms of fish".

29. Cvitanović, Alfonso. Ižani u ribarskim...: 84-85, 105, 120, 123.

30. Verses from Ivan Nardino from Šibenik in his Delle lodi di Sebenico from the $16^{\text {th }}$ century. Described in Fortis, Alberto. Viaggio in Dalmazia, ed. Eva Vianni. Venice: Adriatica di Navigazione-Marsilio, 1986: $131,136$.

31. Until the 1920s fishermen used an "inženj" for red coral extraction. It consists of a wooden crossbow about $4 \mathrm{~m}$ long. A stone weighing about $50 \mathrm{~kg}$ was hung in the middle. At the ends of the cross there were about twenty pieces of honeycomb, knotted with hemp-silk. It is lowered from the boat on a strong rope in the sea, to certain positions, when the rope is taut it is a sign that the 'inženj' is locked. The device alternately rises and is lowered, and is dragged by the boat along the bottom or vertically along the rocks, the crossbow crushes the red corals, whose pieces are smashed into the net. In this way, many other species were destroyed on the sea bed, and only a small percentage of the broken coral was taken out, while most of it is destroyed. Kružić, Petar; Teskeredžić, Emin. "Mogućnost vađenja i uzgoja crvenog koralja (corallium rubrum, Linnaeus, 1758) u Hrvatskoj". Ribarstvo, 60/4 (2002): 154; Basioli, Josip. “Koraljari na našim obalama Jadrana". Radovi Instituta JAZU u Zadru, 15 (1968): 143. 
May to September, which implies that people needed to go back home from time to time (around July 15 and the end of August) to get supplies. ${ }^{32}$ But in the $16^{\text {th }}$ century coral became more commonly used in jewellery, not only for rosaries, but also for ornamental necklaces - to the point that even false coral (corali falsi) necklaces started to emerge. ${ }^{33}$ This change led to a renewed enthusiasm for the

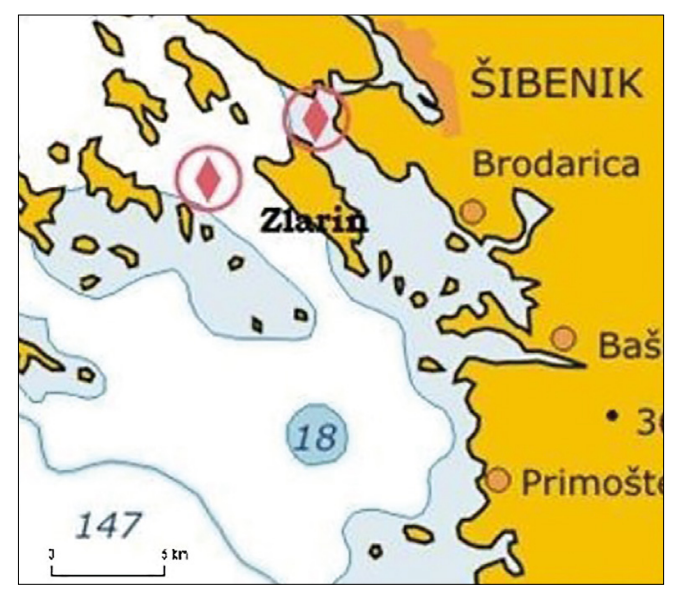

IlLustration 4. Island of Zlarin. Map PRovided by THE AUTHOR.

coral's harvest, which ran from May to September. ${ }^{34}$ There is also some evidence of coral being part of a small trade circuit at that time. In April 1470, two kinds of baskets ( 2 capsus and 1 zonsta) of corals were exported by a local craftsman on the boat of a Ragusan carrier from Korčula (Curzola) to Senj (Segno)..$^{35}$

In the waters of Lastovo, coral harvesting takes place from the $16^{\text {th }}$ century onwards, especially on the north-west of the island of Sušac (Cazza; see Illustration 6). There are black and white corals. ${ }^{36}$ The craze for coral harvesting is such that local guards are absent from their post to go fishing. In the 1540s the authorities asserted that "There are a lot of guards who go fishing fish or pull corals when it's their turn to stand guard. That's why if the fisherman whose turn it is to guard

32. Perić, Jelka. "Lov koralja i spužvara u Dalmaciji". Zbornik za narodni život i običaje, 32/1 (1939): 171.

33. The source only mention this expression of "corali falsi"; it most probably refers to the Myriapora truncata, species of bryozoan. Unlike the real coral, when this fake one is taken out of the sea, the colour fades.

34. Fabijanec, Sabine Florence. "Le rôle économique...»: 872.

35. DAZD. 001 1, Korčulanski knezovi, Andrea Corner, Contraliterre, box 21, B. 37, F. II, f. 8r.

36. Lučić, Josip. "Iz srednjovjekovne prošlosti otoka Lastova”. Radovi sveučilišta u Zagrebu, 6 (1974): 15, $21-23$. 
wants to go fishing, he is obliged to find someone to replace him. If he does not do this, the governor and judges can take a pledge from his home and set up another guard at his expense" ${ }^{37}$ The islands of Lastovo and Sušac are located in Central Dalmatia, the following area of our study.

\subsection{Central Dalmatian islands}

Apart from the standard catching of fish, the aquatic basins of this area also

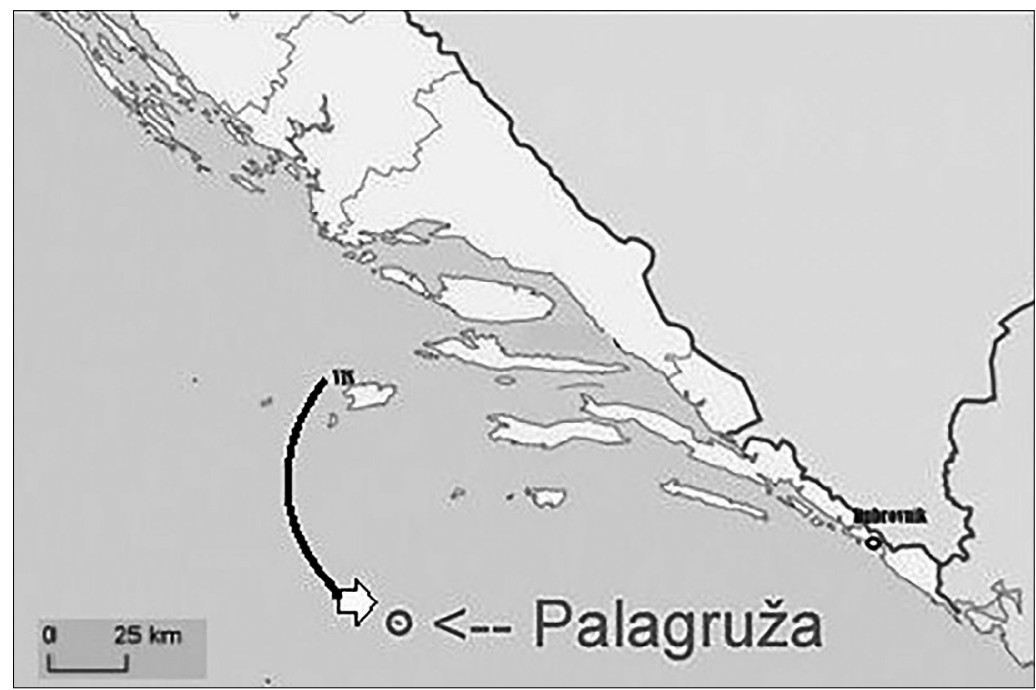

Illustration 5. From the island of Vis to the island of PalagruŽa. Map PRovided BY THE AUTHOR.

allow fishing for lobsters (astacus). They live on rocky bottoms between 60 and 70 $\mathrm{m}$ deep along the coasts of the islands of Lastovo, Mljet, Premuda, Vis (Lissa) and Palagruža. ${ }^{38}$ In the waters around the island of Sušac, west of Lastovo, lobsters are commonly fished. On the island of Vis, fishermen use a fishing net called a kucinôra, 


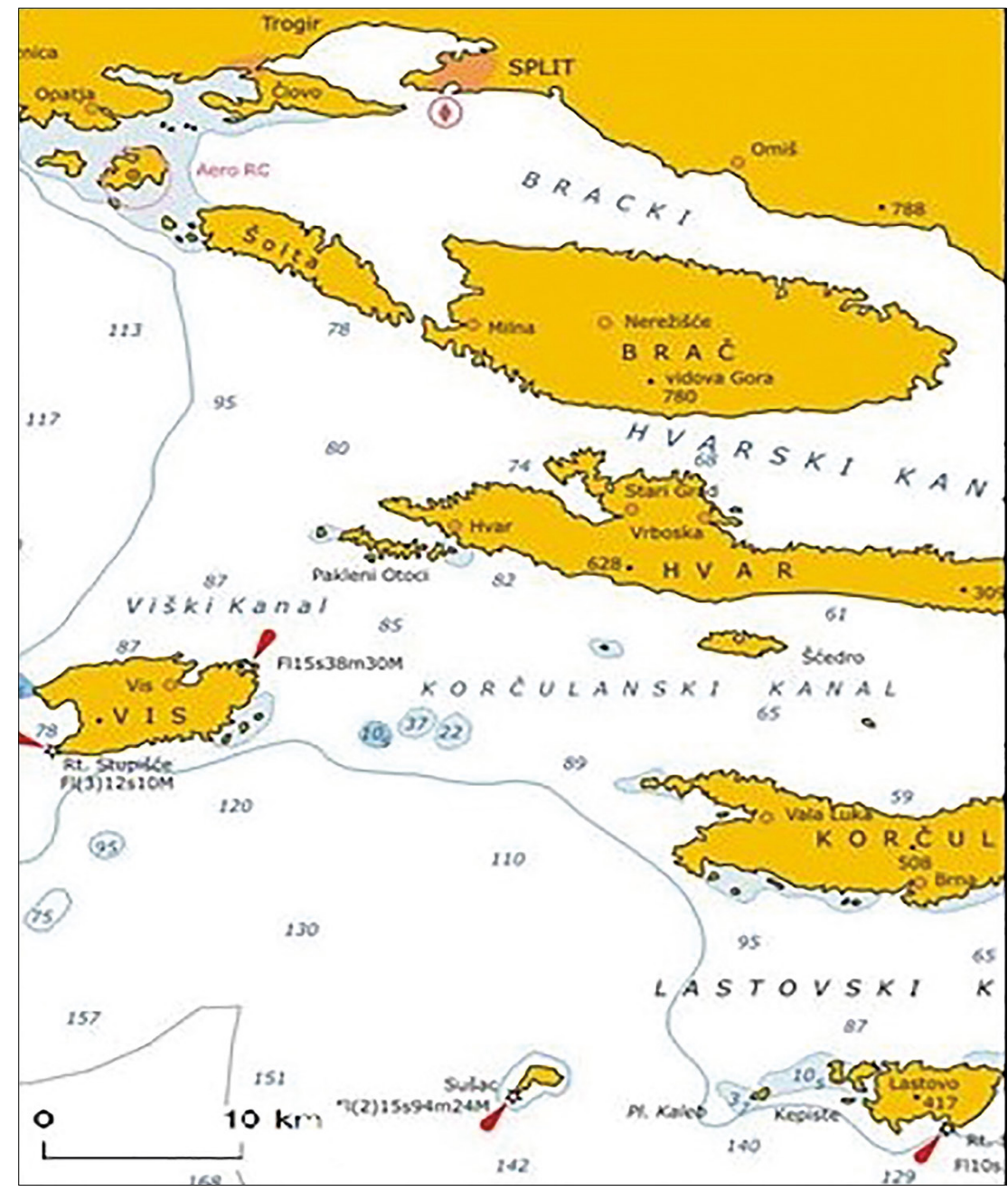

Illustration 6. The islands of Vis, Sušac and Lastovo. MaP PRovided By the AUthor.

whose particularity is to be sewn with large stitches, which is especially effective for lobster fishing in the waters of Vis and Palagruža. ${ }^{39}$

The inhabitants of the island of Vis were famous for their ability to catch sardines. Providing the story is accurate, fishermen from Komiža (Comisa) would have met Pope Alexander III in Palagruža in 1177, when his ship had to find shelter in a storm. They would have contributed to the opulent and joyous dinner for the pope on the island. As a mark of gratitude, the pope granted them the right to fish on

39. Fabijanec, Sabine Florence. «Le rôle économique...»: 871. 
Sundays and holidays. This event would be significant because it means that the fishermen of the island of Vis were already able to navigate the open sea as early as the 12 th century. ${ }^{40}$ For this purpose, they use a specially shaped boat called gajeta falkuša to reach the small island of Palagruža in about five hours of good wind (see illustration 5). The invention of nocturnal fishing at the torch allowed production to increase, thus, in 1553, fishermen caught 3 million sardines in one day. ${ }^{41}$

\subsection{Southern Dalmatian islands}

Further south, the farming of oyster is recorded from 1573 in the area of the bay of Mali Ston ${ }^{42}$ (fig. 8). Shellfish breeding is the privilege of the count of Ston (Stagno), but he gives plots on concessions to private entrepreneurs. Oyster growers have to deliver oyster to the count whenever he wishes and give a compulsory gift during Christmas and other feasts. According to Ragusan diplomatic protocol, mud oysters are offered to foreign distinguished guests. On the market, the oysters are measured by special baskets (košice), whose accuracy is checked in the Ston and Ragusan offices. ${ }^{43}$

Fishing represents an important branch of Korčula's economy. From the $15^{\text {th }}$ century onwards the production of salted anchovy was developed. There are even regular clashes among fishermen over the boundaries of respective fishing zones. Furthermore, allegations concerning nets that were nightly thrown into other territories are made, in this way stealing someone else's fish. The main area of Korčula's waters for fishing was the bay of Lumbarda (see Illustration 7), as testified by some concessions. ${ }^{44}$ Korčula's legal authorities nevertheless face numerous

40. Božanić, Joško. "Milenij ribarstva na otocima viškog arhipelaga», Tisuću godina prvoga spomena ribarstva u Hrvata, Božidar Finka, ed. Zagreb: Hrvatska Akademija Znanosti i Umjetnosti, 1997: $290-291$. 41. Fabijanec, Sabine Florence. "Le rôle économique...»: 871.

42. At Ston they practiced the "Tarentine system" of shellfish breeding, which was the only suitable method for the conditions of small tidal differences in sea level. Skaramuca, Boško; Teskeredžić, Zlatica; Teskeredžić, Emin. “Mariculture in Croatia, history and perspectives". Ribarstvo, 55/1 (1997): 20. At Taranto, the practice of mussel farming is based on the use of particular supporting structures in wood or metal, about ten meters long and commonly called "piles", which are fixed into the bottom to support the ropes and nets used. The mussels grown there are particularly tasty and valued, as they grow in a particular marine environment resulting from the mixture of salt water and fresh water of karstic origin. These particular environmental conditions of the seas of Taranto, thanks to the contribution of numerous submarine springs called "citri", are ideal not only for mussels, but also for fish and crustaceans that find food and shelter among the piles. "Economia di Taranto". Wikipedia. 7 September $2020<$ https:// it.wikipedia.org/wiki/Economia_di_Taranto>.

43. Tomšić, Sanja; Lovrić, Josip. "Povijesni pregled uzgoja kamenica u Malostonskom zaljevu”. Naše more, 51/1-2 (2004): 18-19.

44. Concessa est licentia Pasqualli Vranich posse pischare in confinibus Lumbarde et civitatis et quod quotidie debeat portar pisces ad suficientia cvitatis valeat pro diebus quindecim tanta M.d. C. confirmavit per totum menses augusti cum conditionibus. (7 May1478); Concessa est licentia Perino Vlachusich posse piscare in confinibus Lumbarde et civitatis cum eius tracta et quod quotidie debeat portare pisces ad suficientas civitatis valeat per diebus quindecim tantum MdC confirmavit per totum menses augusti cum condicionibus suprascripte. (8 May 1478); Concessa est licencia Zivcho Braienovich posse pischare in confinibus Lumbarde et civitatis cum eius tracta et quod quotidie debeat 


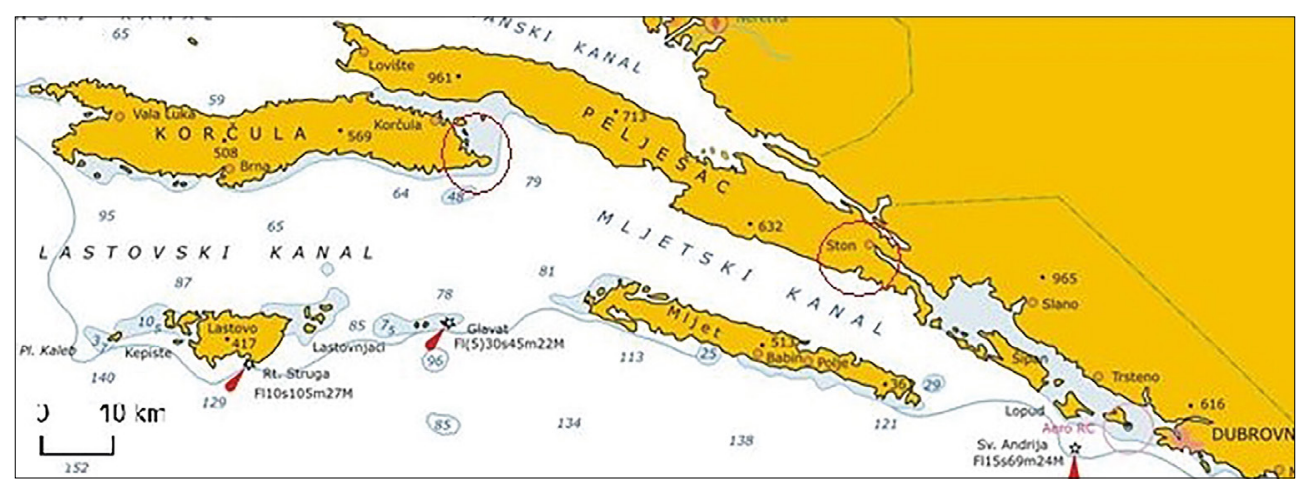

Illustration 7. The bay of Ston and bay of Lunbarda on KorČUla. Map provided by the author.

attempts of fraud, such as throwing nets overnight in areas leased by others, not declaring the entire fishery - (for example, in 1450 Marinacius and his cousin Ratko, fishermen in the village of Lumbarda, report only $10 \%$ of the mackerel caught), the damaging of hedgerows by the passage of nets on the ground, the illegal possession of nets, and numerous other cases. ${ }^{45}$

\section{Basic rules and fishing techniques}

The nets are folded by hand with thread of plant origin. Their shape and size depend on the type and size of the fish caught, the type of fishing, the position of the cove and of the seabed where fishermen fish, the fishing season (at day or at night), whether they stand immobile at sea or they are drifted. ${ }^{46}$ We can here summarize some of the steps in the technical development that has taken place over time.

The accusation levelled by the Benedictine monastery of St. Krševan in Zadar against fishermen that they do not give up their share of chub mackerel as they should, brings to light important information. By means of the charges laid out by the prosecutor, dating back to 1223, we learn about the first use of a kind of small driftnet called gripis piscantur, ${ }^{47}$ as a prototype of the bigger driftnet named later tratta

portare pisces ad sufiscientiam civitatis valeat pro diebus quindetim tantum mdc confirmavit per totum mensem augusti cum conditionibus suprascripte. (8 May 1478); DAZD. 0011 , Korčulanski knezovi, Pietro Nani, box 25, B. 48 , F. X, f. 12 r.

45. Schmitt, Oliver Jens. Korčula sous la domination de Venise au XVe siècle. Pouvoir, économie et vie quotidienne dans une île dalmate au Moyen Âge tardif. Paris: College de France, 2011: 13-15.

46. Cvitanović, Alfonso. Ižani u ribarskim...: 147.

47. Codex diplomaticus Regni Croatiae, Dalmatiae et Slavoniae, ed. Marko Kostrenčić, Emilije Laszowski. Zagreb: Academia Scientiarum et Artium Slavorum Meridionalium Auxilio Regiminis Croatie, Dalmatie 


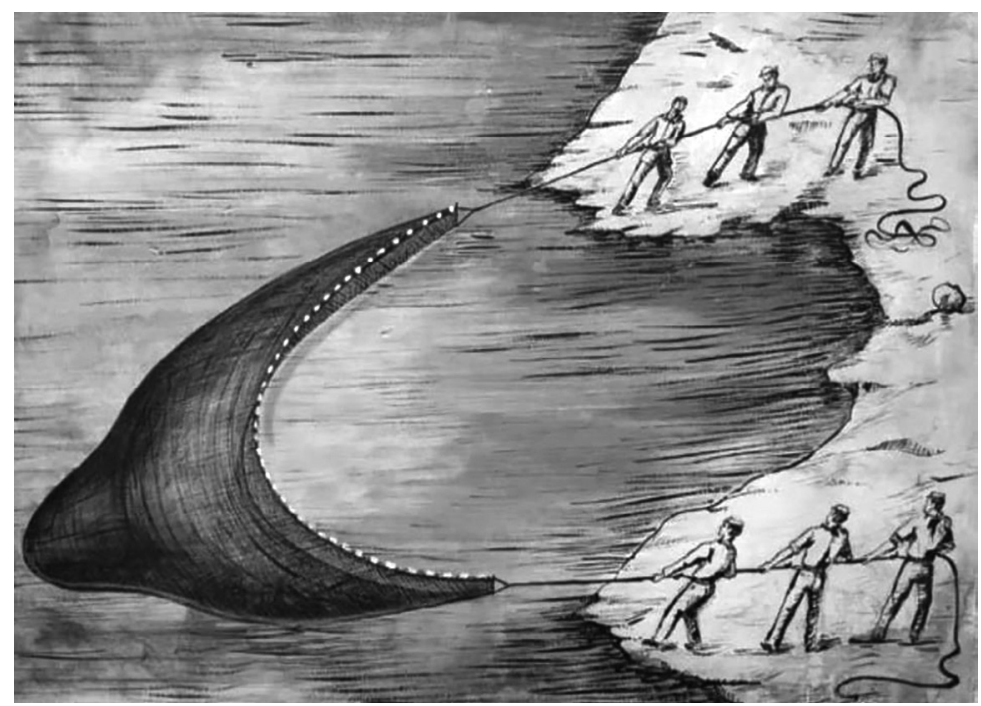

Illustration 1. Driftnet. (Rosić, Tea. Rogi ribaru O ribarstvu Crikvenice i okolice. Crikvenica: Muzej Grada Crikvenice, 2011: 30).

in the records (illustration 1), specialized in the catching of dark-fleshed fish. ${ }^{48}$ Over time, fishermen assign specific names to the nets according to the species of fish caught. From 1566, for instance, the term sardelliera or srdelara (in Croatian) was used for driftnets desined for catching sardines. ${ }^{49}$

Beside driftnets, fishermen use fixed gillnets (retti calate; illustration 2). Gillnets are a passive kind of net, they catch only what gets caught in their net meshes. They can be set close to the shore or in the open sea, at night and in the moonlight and even during the day (per die et per nocte). A vessel with a crew of 4 to 6 fishermen is used to set up a fixed gillnet. ${ }^{50}$

In Šibenik, if upon departure or return some fish are caught for travel rations for the needs of the crew and passengers, it is not considered theft. But if the value of the catch exceeds 10 pounds a fee of 25 pounds must be paid to the commune. ${ }^{51}$ On the island of Murter (Morter) a contract dating back to 1503, explicitly states that Šime Ratkić bought fishing gear with lighting (vnius capse et luminarii a piscando) from the merchant of Šibenik Filip Rudatović. The lighting

et Slavoniae, 1905: III, 385-386 (doc. No. 332).

48. Županović, Šime. "Ribarstvo i ribarska terminologija zadarskog područja». Čakavska rič, 22/2 (1994): 6; Cvitanović, Alfonso. Ižani u ribarskim...: 123.

49. Cvitanović, Alfonso. Ižani u ribarskim...: 145-146.

50. Cvitanović, Alfonso. Ižani u ribarskim...: 123.

51. Kniga statuta, zakona i reformacija grada Šibenika, ed. Slavo Grubišić, Zlatko Herkov. Šibenik: Muzej grada Šibenika, 1982: book 6, § 58, 133. 


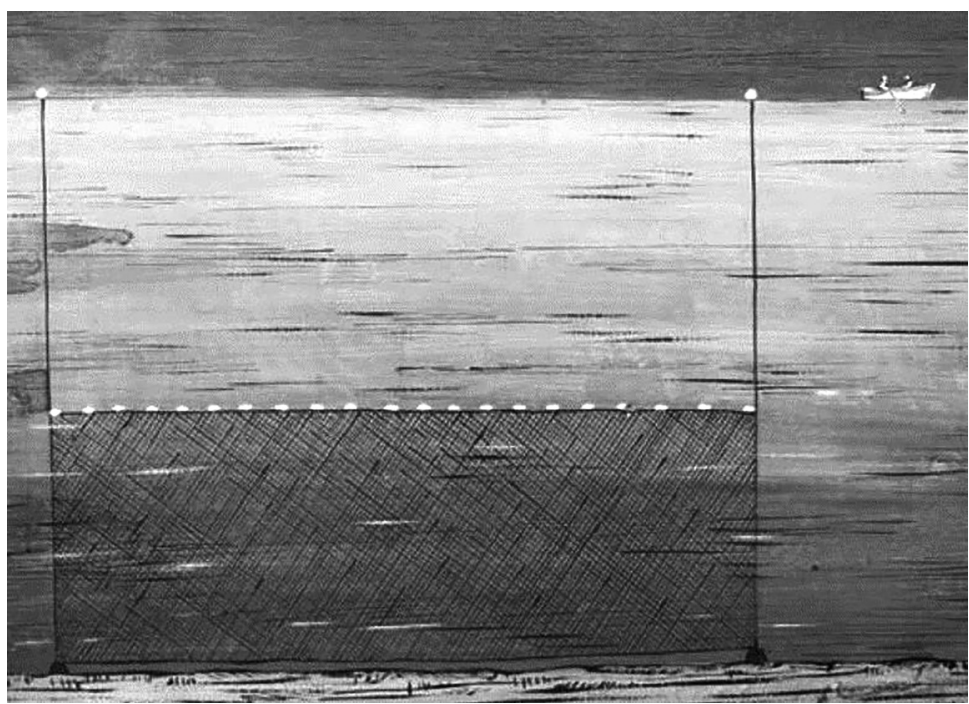

Illustration 2. Fixed gillnet (Rosić, Tea. Rogi ribaru O ribarstvu CRikVenice i okolice. Crikvenica: Muzej Grada Crikvenice, 2011: 29).

consisted of burning blackcurrant branches or dry vines place on an iron fishing 'candlestick' called a svečnjak (Illustration 3). Murterins are hired by other fishermen, as evidenced by the contract of 1553, in which Šime Cvitulović gives his son as worker to the patrician ser Jakov Grižinić, to serve him one year at the fishery of Žirje (Zuri) (ad pischeriam Azurorum)..$^{52}$ On Murter, hooks, kiddles, spears, small coastal driftnets and so on were used, while there was no fishing net for the open sea. ${ }^{53}$ The use of light for night fishing introduced at the beginning of the $16^{\text {th }}$ century ${ }^{54}$ is combined with the introduction in 1524 in Zadar of an improved driftnet model for catching sardines on the open sea and has a significant impact on the development of fishing and the growth of the fish export trade. Thus, to catch dark fleshed fish, fishermen would travel up to 15-18 nautical miles from the coast on a summer night, and spend nearly

52. Juraga, Edo. “Nazivi riba u govoru Murtera”. Čakavska rič, 41/1-2 (2013): 190.

53. Juraga, Edo. “Nazivi riba u jezerima na otoku Murteru”. Čakavska rič, 36/1-2 (2008): 133.

54. For the night fishing, a fishing boat is anchored with deployed net inside the fishing ground, while two others boats, called kajić, are roaring with the light, in order to find out where are the fish. Once the two kajić have founded the school of fish, the lights are gradually reduce or shut off, while paddlers hit slowly the water in order to unite the school and then to lead the fish towards the fishing ground. The connection point depends on the type of fish and the depth of the sea (starts by a depth gauge called "kalumica"). Once the school comes close enough to the fisherman, he starts to lower the net. They then pulled the net manually into the fishing boat. During one night this procedure is repeated several times; Rosić, Tea. Rogi ribaru O ribarstvu Crikvenice i okolice. Crikvenica: Muzej Grada Crikvenice, 201 1: 25. 


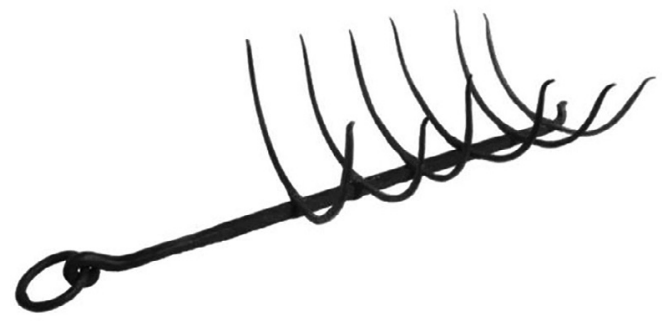

Illustration 3. Iron "CANDle STICK" FOR Fishing (sveČNJak). Rosić, Tea. Rogi ribaru O ribarstvu Crikvenice I okolice. Crikvenica: Muzej Grada Crikvenice, 2011: 73. twenty days at sea. ${ }^{55}$ For their stay fishermen built temporary huts; these structures included ones for storage and for the salting dish on site. On the archipelago of Kornati (Incoronate), the fishing port of Piškera (Italian peschiera) had about fifty houses, shanties, sheds for salting fish, and even a tower to defend against pirates. In 1532, the Venetian authority had a citadel built on the nearby islet of Velika Panitula to collect the tax. ${ }^{56}$

The fish-rich waters of the Zaratin insular zone attracted

other Dalmatian fishermen. In 1485, people from Šibenik needed to pay a tribute (an eighth of the catch) to get the right to use the communal waters and to sell fish in the Zaratin market. ${ }^{57}$ In Lastovo, the local authorities protected their fishing zone by restricting the possibility of the Ragusan fishermen catching fish around the island. In the 1490s they forbade the fishermen of Dubrovnik from building small houses and huts on the island as they had previously done. From then on Ragusans could only use the existing huts in the specific district of Saint-George; any huts built afterwards were destroyed. ${ }^{58}$

In Split, unlike fish caught for sale on the market, the import of fish to the commune for private consumption is not taxed. Individual fishermen can import fresh or salted tuna without paying customs. In contrast, salted fish intended for Venice or other places are taxed. ${ }^{59}$ Thanks to the success of large driftnets, the number of fishermen owning such nets increased: in 1579, 98 owners are registered for the right to fish in the fishing zone around the islands of Vis and Biševo (Busi). However, with the increase in the number of sardine

\footnotetext{
55. Fabijanec, Sabine Florence. "Fishing and the fish trade...": 370, 372-373. See fish trade's evolution in this paper.

56. Grbin, Nedo. “Ribe, more i ribarstvo u saljskim glagoljskim rukopisima”, Tisuću godina prvoga spomena ribarstva u Hrvata, Božidar Finka, ed. Zagreb: Hrvatska Akademija Znanosti i Umjetnosti, 1997: 90.

57. Fabijanec, Sabine Florence. "Fishing and the fish trade...": 376.

58. Lastovski statut, ed. Vladimir Rismondo. Split: Književni Krug, 1994: 255, § 94.

59. Che ciascuno pescador in Dalmatia qual condusse a Spalato pesce fresca over tonina frescha over salata per uso suo non sià tenuto paggar $i$ datio salvo per pesce salado il qual val a Venetia over per altri luoghi eccerto che se de Dalmatia fusseno condutti alla cità de Spalato ("That each fisherman in Dalmatia who brings fresh or salted fish or tuna in Split for he's own use doesn't need to pay taxes, except for the salted fish that goes to Venice or if from other places out of Dalmatia they are conducted to Split"). DAST. 1 (IX Incantus datii XXXni Johannis Aloysii Delfino conte et capitaneo di Spalato), ff. 355r-356r (February 1539).
} 
specialised fishermen (called srdelars) came an increase in the number of disputes among the owners of big and small nets. ${ }^{60}$

In addition to professionally led fishing, fishing was also practiced by individuals. This is the case, for instance, of shepherds engaged by a merchant company from Zadar during the second half of the $15^{\text {th }}$ century who lived on an island in the Zadar archipelago. Among their tools is equipment for night fishing: lantern (feral), spear (fosina), sting (pido), grid (gradela), and hollow-ended sticks (stumuli) used to hit the sea and scare the fish to make it easier to catch them in the net. ${ }^{61}$

Similarly, sailors sometimes fished to complete their daily provisions on board. A French pilgrim on a trip to Jerusalem in 1470 describes a tool used by the ship's crew on board. His report also contains a valuable drawing (illustration 4) that provides visual support to his topic. So, the sailors catch sarda and tuna with an instrument they call fossina, which is a long stick the end of which is iron with several teeth, made in the manner of turquoise arrows'shape. They dart this spear at the fish when it approaches the net, which afterwards they withdraw by means of a rope attached to it. ${ }^{62}$

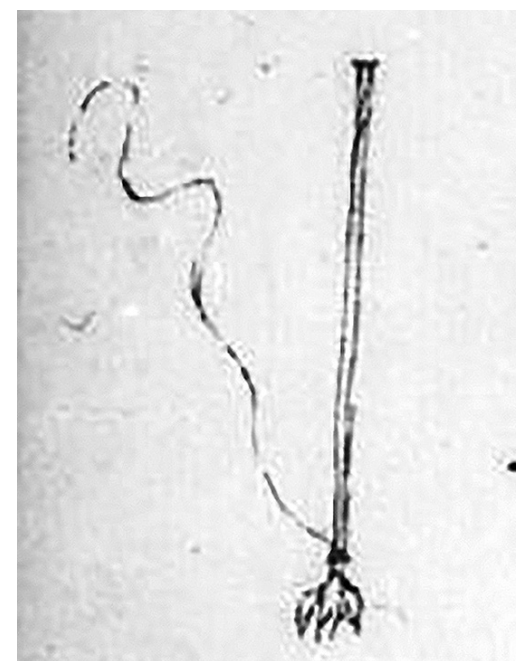

Illustration 4. Fossina (PRonged SPEAR) FROM RELATION DU VOYAGE FAIT PER LUI DANS LE LEVANT, EN LA COMPAGNIE DE JEAN-JACQUES BREUNING, By JEAN Carlier de Pinon (BnF. Département Des manuscrits. Français, Ms. 6092, F. 12v.).

\section{Communal fish market: rules and prices}

The majority of the statutes require that the fish caught the night before are sold exclusively to the fish market of the city. Fishermen must share a specified amount of the catch among the notables of the commune before selling the rest

60. Županović, Šime. “O zabranama lova srdela mrežama srdelarama na Visu kroz stoljeća”. Adrias, 1 (1987): 76-79.

61. DAZD. 0019, Spisi obitelji Matafar, box 1, V. 1, ff. 67r, 70r-70v, 110r-110v.

62. BnF. Département des manuscrits. Français, Ms. 6092 (Carlier de Pinon, Jean. Relation du voyage fait per lui dans le Levant, en la compagnie de Jean-Jacques Breuning), f. $12 \mathrm{v}$. 
in a previously arranged place. ${ }^{63}$ Thus, in Pag, the mackerel caught in Caska Bay must only be unloaded on the communal dock. The fish can be sold once all the crates have been unloaded from the boat. In cases of non-compliance, the fine is 40 cents and the fisherman loses his fish. Mackerel should not be purchased in large quantities for export, but only for local consumption. In this case the fine is 10 pounds. ${ }^{64}$ While in all communes only fishermen are allowed to sell fish, an exception seems to be the island of Rab. Everyone here, "whoever he wants" could sell fish even without scales, because it was a custom. The seller needs only to pay tax of one eighth on all the fish sold. ${ }^{65}$ In Skradin (Scardona), fishermen store their nocturnal fishing gear, including the lantern, the net and the fire bat used to scare the fish in a depot belonging to the city without giving a share to the notables. But if returning from night fishing they expect to leave in daylight for fishing, then in this case they must give some of the fish to the count and to the judges. ${ }^{66}$

\subsection{Prices of fish}

Among other regulations, communal statutes define the prices of the markets (table 2). As can be seen in the fresco of the fish seller (illustration 5), there existed quite a wide variety of sea products in Croatian maritime communes. Prices sometimes varied depending on the holiday season. In some communes (Rijeka) fish is less expensive in Lent, in other communes (Pula) it is more expensive over the same period. As can be seen, the most expensive fish were tuna and ray in Rijeka, and cuttlefish in Split.

Table 2. Prices of fish according to the statutes (price per pound)

\begin{tabular}{|l|c|c|c|c|c|c|}
\hline City Fish species & $\begin{array}{c}\text { Split } \\
(\mathbf{1 3 1 2})\end{array}$ & $\begin{array}{c}\text { Skradin } \\
\mathbf{( 1 3 0 4 - 1 3 1 2 )}\end{array}$ & $\begin{array}{c}\text { Trogir } \\
\mathbf{( 1 3 2 2 )}\end{array}$ & $\begin{array}{c}\text { Pula } \\
\mathbf{( 1 4 3 1 )}\end{array}$ & $\begin{array}{c}\text { Krk } \\
\mathbf{( 1 4 7 0 )}\end{array}$ & $\begin{array}{c}\text { Rijeka } \\
\mathbf{( 1 5 3 0 )}\end{array}$ \\
\hline Red mullet & - & 5 denars & 5 denars & 18 denars & - & - \\
\hline Eel & - & 5 denars & 5 denars & 12 denars & & - \\
\hline Dentex & - & 5 denars & & 12 denars & - & - \\
\hline Conger bream & - & 5 denars & - & 12 denars & - & - \\
\hline
\end{tabular}

63. Fabijanec, Sabine Florence. "L'influence des pouvoirs publics sur le commerce et sur la vie des marchés urbains en Dalmatie (XIII ${ }^{e}$-XIV siècles)». Mediaevum Quotidianum, 48 (2003): 44-46.

64. Basioli, Josip. Tunolov na Jadranu ...: 47.

65. Statut rapske komune iz 14. stoljeća, ed. Lujo Margetić, Petar Strčić. Rab-Rijeka: Grad Rab-Adamić Rijeka, 2004: book 4, 169, § 6.

66. Statut grada Skradina, ed. Ante Birin. Skradin: Matica hrvatska, 2002: 197, § 25. 


\begin{tabular}{|c|c|c|c|c|c|c|}
\hline Mackerel & 2 denars & - & 4 denars & 12 denars & - & - \\
\hline Red scorpion fish & - & - & - & 12 denars & - & - \\
\hline Tuna & 3 denars & - & 4 denars & 12 denars & - & 12 denars \\
\hline Leerfish & - & 5 denars & & & - & - \\
\hline Scad & 2 denars & - & & & - & - \\
\hline Fish with scales & - & 4 denars & 4 denars & - & - & 2 denars \\
\hline Small fish & 2 denars & - & 3 denars & 10 denars & 12 denars & - \\
\hline $\begin{array}{l}\text { Sharks (cat, angel, } \\
\text { bluntnose six gill) }\end{array}$ & - & 2 denars & 2 denars & 6 denars & - & - \\
\hline Ray & - & - & 1,5 denars & 6 denars & 4 denars & 8 denars \\
\hline Blue skate & - & - & & 6 denars & - & 6 denars \\
\hline Moray & - & - & 5 denars & - & - & - \\
\hline Oyster & - & - & - & - & 6 denars & - \\
\hline Octopus & - & 3 denars & 3 denars & $\begin{array}{l}\text { by rule of } \\
\text { thumb }\end{array}$ & 6 denars & - \\
\hline Cuttlefish & 8 denars & 3 denars & & $\begin{array}{l}\text { by rule of } \\
\text { thumb }\end{array}$ & 6 denars & - \\
\hline Squid & - & 4 denars & 3 denars & $\begin{array}{l}\text { by rule of } \\
\text { thumb }\end{array}$ & 8 bagatins & - \\
\hline
\end{tabular}

In spite of the statutes, the city authorities were faced with various attempts of fraud or infringements of the rules. As a result of this, new measures called Reformationes were introduced. In Šibenik, in 1428 a Reformation rule criticizes the "acerbity of the fishermen, who are often so without shame that they have no regard for their lord governor". The fishermen refuse to sell him fish at lower price than it is sold to others. In response to the seriousness of such irregularities (duritias $\theta$ enormitates), it is decided that on days when meat is not sold or eaten no fisherman or fish seller is permitted to sell any fish before the governor's representative has taken the fish he requires. ${ }^{67}$ In Rovinj, the authorities were confronted with the problem of theft. Fish crates (canestri di pesci) destined for the fish market are stolen. To protect itself from these thefts, the commune decides that anybody who takes a basket without the license of the fish owner should pay a fine of 20 pennies. $^{68}$

67. Kniga statuta, zakona i reformacija...: Reformatione 1428, 293.

68. Statuti municipali di Rovigno, ed. Pietro Kandler. Trieste: Tipografia del Lloyd Austriaco, 1851: § 15, 105 ("Di non metter mano nelli Canestri"). 


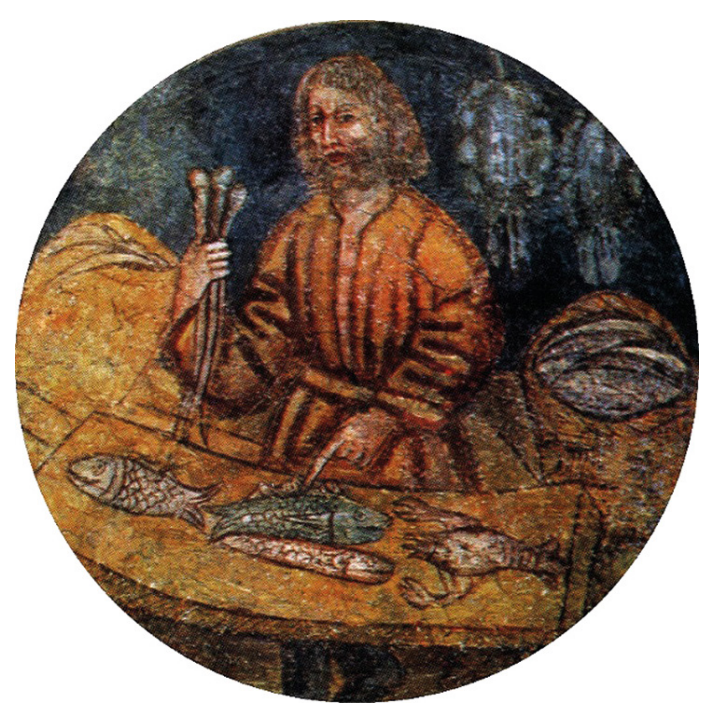

Illustration 5. Fish SELler With HIS WAREs. We CAN SEE TURTLES AT THE BACK, EELS IN HIS HAND, A BAG AND BASKET FULL OF FISH, AND COMMON LOBSTER ON THE BENCH. FRESCO By IVAN OF KastaV IN THE CHURCH OF THE Holly Trinity (Hrastovlue, Slovenia), 1490. Picture PROVIDED BY THE AUTHOR.

\subsection{Kitchen accessories in daily life}

There are a few researches which look at the domestic side of the preparation, cooking and consumption of fish. In Šibenik inventories written after a person's death list the goods that had belonged to the deceased. Most households usually have a number of pots and pans for cooking. According to the statistics established from these inventories, meat consumption dominates that of fish. For example, in the kitchen of the goldsmith Pavao Derljanović in 1459, of 22 pans only one is characterized as una ferssora da frizer pese (a frying pan for fish). In 1471, the blacksmith Cvitan also possesses an una padella de fero da frizer pesse. ${ }^{69}$ In the customs'

69. "iron cooking pan for frying fish". Budeč, Goran. "Kuhanje, pečenje i blagovanje: pribor za jelo i kuhinju u kućama kasnosrednjovjekovnog Šibenika", Domus, casa, habitatio...: kultura stanovanja na jadranskom prostoru, Marija Mogorović Crljenko, Elena Uljančić-Vekić, eds. Poreč: Zavičajni muzej Poreštine-Sveučilište Jurja Dobrile u Puli-Odjel za humanističke znanosti-Državni arhiv u Pazinu, 2013: 54-72. 
records of the Dalmatian commune expressions like per la messa or per tramesso $0^{70}$ appear relating to the cooking utensils declared by crews. Most of the time the records show the inclusion of salted meat, sardines, cheese, figs, honey and a lot of barrels of wine. The above-mentioned fossina attest as well that sailors used to eat fresh fish on board, such as sarda and tuna. Cooking on board is as important as being well armed. Two members of the urban nobility of Šibenik brought cooking utensils with them on board when they sailed to a Crusade. Among them are II gradelle una pizola e una granda and I fersora granda da frizer de rame. ${ }^{71}$ There is also the usual meza barilla de sardelle in brine. ${ }^{72}$

\section{To conclude}

All along the eastern Adriatic coast, in shallow waters or in the waters of remote offshore islands, fish, shellfish and other seafood have long been abundant. Thanks to the rise of new net patterns and fishing techniques at the end of the $15^{\text {th }}$ century, catching fish became easier and more productive. Despite these advantages, numerous conflicts more and more have risen concerning fishing rights and draws to acquire the most propitious fisheries ${ }^{73}$ — some of which became lawsuits lasting several centuries! Knowing that the Christian calendar includes between 150 and 250 days of meatless fasting (for lay people or clergy), we understand the importance of the consumption of fish. However, in everyday life, there is evidence to show that there were fewer frying pans for fish than there were various pans, cauldrons and other utensils used for cooking meat - bearing witness to a moderate observance of the precepts of the Church.

\footnotetext{
70. The goods described in the context of messa would suggest that it is food consumed for food, snack, meal during the travel. It can be relying on the mess deck aboard ships, originated from the Latin verb mittere, with its original meaning "a course of a meal put on the table". Since in the expression tramesso there is the word tra-, which the meaning can be related to the Italian "between", it would be maybe possible to make a slightly difference between the food of the regular collation and the food eaten "in between" the meals. But since in these period the vocabulary is far to be fixed and that words are frequently used with lot of polysemy, it can be only a possible interpretation, not at all a final translation in English or any other language.

71. "two griddles, one small and one big", “a big cooper pan for frying".

72. "half barrel of sardines". Budeč, Goran. “Osobni predmeti vojnih zapovjednika na pomorskom pohodu. Primjer materijalnih predmeta šibenskih patricija ser Tome Tomaševića i ser Šimuna Tavelića na križarskom pohodu 1463 godine". Zbornik Zavoda povijesne i društvene znanosti HAZU, 34 (2016): 100, 102.

73. During the Carnival period, the owner of a fishing boat equipped for tuna fishing made an oral agreement with his future crew members - this way every year were formed groups of eight to ten fishermen. The active season of tuna fishing is from April to October. Conflicts may have arisen because the fishing grounds every year were drawn at the same time as the group name. But some bays were less favorable than others; moreover landowners privatized some fishing grounds to the detriment of local fishermen or changed the rules of the fishery duties.
} 